\title{
English Teachers' Effectiveness and Students' English Proficiency at Selected Colleges in Dili, East Timor: Input for Enhancement Programs
}

\author{
Bogor Lumbanraja ${ }^{1} \&$ Lino C. Reynoso ${ }^{2}$ \\ ${ }^{1}$ Universitas Katolik Santo Thomas, Indonesia \\ ${ }^{2}$ Adamson University, Manila, Philippines \\ Correspondence: Bogor Lumbanraja, Universitas Katolik Santo Thomas, Indonesia.
}

Received: June 6, 2019 Accepted: September 24, 2019 Online Published: September 26, 2019

doi: 10.5539/elt.v12n10p96 URL: https://doi.org/10.5539/elt.v12n10p96

\begin{abstract}
This research is designed to determine the relationship between English teachers' effectiveness and students' English proficiency at Selected Colleges in Dili, East Timor, as input for enhancement programs. The English teachers' effectiveness consist of three aspects namely (1) English Proficiency, (2) Pedagogical Knowledge, and (3) Socio-Affective Skills. Meanwhile, the students' English proficiency was measured in terms of the following aspects: (1) Listening, (2) Writing, (3) Reading, and (4) Speaking. The collected data is analyzed by using the Statistical Package for Social Sciences whereby charts, figures and tables were used to present the findings.

The overall mean for English Teachers' Effectiveness is 3.64, interpreted as effective. This implies that English Teachers at Selected Colleges demonstrate the effectiveness required of them, but it is in Socio-Affective Skills that they are performing best.

The overall mean for Student Respondents' Level of English Proficiency is 3.85, interpreted as good. Observing closely, the mean score of speaking which is 3.51 is close to "Average" (down) because in the Range of Mean Values of $2.51-3.50$ is Average.

The results of the Pearson Correlation showed that all independent variables on English teachers' effectiveness are correlated with the dependent variable on students' English proficiency. The correlation coefficient values are between of \pm 0.50 to \pm 0.74 , which means "High or Strong Relationship".

Based on a reasonable output of this study, the researcher proposed training programs to enhance the English teachers' effectiveness and students' English proficiency in Selected Colleges in Dili, East Timor.
\end{abstract}

Keywords: effectiveness, English proficiency, pedagogical knowledge, socio-affective skills, East Timor

\section{Introduction}

English has immensely spread across the globe in many ways. As English has constantly been spreading around the word, it is no longer a language that only deals with countries where English is used as the first language (mother tongue). Vu (2014), argued that English does not only belong to English people or Americans. The English language now belongs to all who use it. The strong role of English in the world has led to the recognition of English as global language worldwide (Siregar, 2010; Silalahi, 2016).

All over the world, there is also the increasing phenomenon of student migrants to the colleges and university who use English as an introduction to the teaching and learning process. Students seek to study in universities where English is the medium universities despite language difficulties because they see the potential gain for their future (Chuah, 2009). English proficiency seems to be an important (though not the only thing) entrance to education that is easily recognized and valued internationally (especially in the world of work). For example, it is common for workers to be asked to translate their diplomas and documents according to English standards (Appleby, 2009).

As early as the onset of East Timor's independence, English was already considered an important language for communication. This was brought by the wave of foreign influences when the United Nations took over the country, and adopted English as the language of communication during the transitional period. Since that time, 
there was an observed increase in the use of English. With the influx of international agencies, English has become very important, the demand for English is very high (Quinto, 2015). In the government, the main areas of need in English are effective communication in the workplace, short-term professional development abroad, and advanced study at under-and post-graduates levels (Barreto, 2009).

Young (2009), reported that in East Timor, documentation of the use of English seems to be lacking despite there is an interest in developing the language use similar to the other Southeast Asian countries. It is because the revision of educational system in this country is quite slow. Consequently, this country cannot make a realistic plan for foreign-language teaching. "The main challenges facing recurrent education are the need to increase the number and quality of classes under the post-literacy program so that gains in literacy are sustained, the need to improve conditions for monitors and teachers and provide better professional development opportunities, improvi

Timorese students study English as foreign language only in classrooms where the amount of time available for learning English is not enough to give space and opportunity for students to practice their English adequately. In addition, despite the availability of a number of English-language radio satellites and television stations, as well as the internet, a large number of students do not hear or read English news in those media (Dos Santos \& Belo, 2008; Almeida, 2014). Therefore, it could be claimed that absence and lack of performance and practice of English is one of the major reasons behind many students' serious communication difficulties.

The deficiency in the use of English language has been a matter of great concern by considerable number of educators in East Timor who apparently put the blame on the allegedly arbitrary policy of the simultaneous emphasis on Tetun (or Tetum) and Portuguese as the basis of the national language. The prevalent use of Tetun (or Tetum) and Portuguese has not given English the significance it deserves as means of international linguistic communication fully (Appleby, 2009; Da Silva, 2013).

In a nutshell, it is necessary to explain the spread process, role, influence, function and importance of English in a global or world scale, the regional scale of Southeast Asia, ASEAN countries, East Timor itself and specifically the role and existence of English in schools. Furthermore, the researcher wants to focus more on the problems in the English teachers' effectiveness in relation to English proficiency of the students especially at Selected Colleges in Dili, East Timor.

\subsection{Statement of the Problem}

In order to understand the problem, specifically, it sought to answer the following questions:

1) What is the level of English teachers' effectiveness as assessed by the student-respondents in terms of the following components:

English Proficiency;

Pedagogical Knowledge;

Socio-Affective Skills

2) What is the level of the English proficiency of student-respondents in terms of the following components of listening, writing, reading, and speaking?

3) Is there a significant relationship between the level of English teachers' effectiveness as assessed by the student-respondents and the level of English proficiency of students?

4) What are the opportunities and challenges that the teachers encountered in teaching English among students?

\subsection{Hypothesis}

This study tested the following null hypothesis:

There is no significant relationship between English teachers' effectiveness and students' English proficiency.

\section{Literature Review}

\subsection{Effective English Teacher}

Effective teacher and effective teaching is strongly related to effective learning. In this concept, the characteristics of an English teacher are very important to understand and understand problems and difficulties that can hinder students from a long learning process. This study presents a literature review of an overview of the effectiveness of English teachers who possess general characteristics contained in previous studies, and gave a number of pedagogical proposals to English teachers about how to improve their effectiveness in the classroom. More than 30 studies in the field of foreign language education show the characteristics of effective English 
teachers. Mostly cited in this study were grouped into three: (1) English proficiency, (2) Pedagogical Knowledge, and (3) Socio-affective Skills.

It would be helpful to define the following terms: effective, effective learner and effective teacher in some degree. The concept of "effectiveness" is perceived and interpreted differently by various researchers in different fields such as health, science, social sciences, law and so on. Apart from differences in perceptions of effectiveness, there are similarities in understanding of effectiveness, namely being successfully producing a desired or planned outcome (Oxford Advance Learner's Dictionary, 2009). Furthermore, effective learners are very closely related to successful learners who set and complete their goals (Mutlu \& Ozkan, 2017). Defining effective teacher may be totally or partially true from various perspectives (e.g. Sishavan \& Sadeghi, 2009; Riasati \& Bagheri, 2014).

The definitions of terminology that cannot be ignored include personal, potential, socio-economic, cultural, and field based on the personal aspects that distinguish them. Recognizing differences in definition, it is rather difficult to provide a general definition that is suitable for the general teaching context such as at the elementary, secondary and university levels. However, in general, focusing on from teaching and education, effective teachers can be described as someone who should have accompanied students to higher achievement and long learning processes (Noora, 2009; Vasudevan, 2013). It is naturally that a teacher has characteristics that are unique in his field and in other general fields (Dincer, 2013). It is naturally that a teacher has characteristics that are unique in his field and in other general fields.

There is still no consensus on the determinants. Thus, the definition of an effective English teacher varies in terms of perspective differences such as affective, class management, and knowledge fields. On this issue one thing can be seen that a good language teacher is someone who empathizes with his students, presents meaningful communication in the context of the classroom and encourages the self-esteem of his students (Makewa \& Role, 2013). Nara (2015) focused on in education and the field of teacher knowledge; and guide a good language teacher who uses target language attainment, has good and clear pronunciation, emphasis and intonation, involves students in activities and is flexible that leads to its objectives. Poornima (2014) determined the test donations from a communication point of view; and reports that students have completed their educational goals with regard to communication effectiveness.

Be aware of the above perspective in the field of teaching in general and the multi-dimensional perspective on the attributes of an effective English teacher, some pedagogical aspects for English teachers and how to increase their effectiveness in the classroom have been noted. To summarize the three main characteristics of effective English teachers including English language proficiency, pedagogical knowledge and social affection skills as mostly cited in the literature (Park and Lee, 2009; Shishavan and Sadeghi, 2009; Zamani and Ahangari, 2016).

\subsection{English Proficiency.}

English proficiency is the ability to hear, speak, read and/or write in English. To be truly proficient, someone must have advanced skills in all four areas of communication. Proficiency is about performance. It's about the ability of appearance in language according to the demands of the situation in the classroom to deliver lessons according to language targets and targets, especially if we are moving on a more efficient approach (Riasati, 2014).

Answering the increasing need for English communication skills, many Asian countries where English as a foreign language has been taught recently since elementary school level. However, most teachers in primary schools in such countries are not adequately prepared to teach English; improve English proficiency and teaching skills which then become a kind of ( Vu, 2014).

Park (2019) investigated the characteristics of effective English language teachers as revealed by 169 teachers and 339 students in high schools in South Korea, by answering questionnaire sheets consisting of three categories: English language proficiency, pedagogical knowledge, and socio-affective skills. Overall, teachers understand the characteristics differently from students in all three categories where the teacher ranks English proficiency as the highest contrary to students who make pedagogical knowledge the highest. In the sub group of students also make different perceptions about effective teaching. Smart students (high-achieving students) report (reported) pedagogical knowledge as the highest, while less intelligent students (low-achieving students) see socio-affective skills as the highest. This discovery has an effect on the basic knowledge of teacher education now and in the future.

\subsection{Pedagogical Knowledge}

Foreign language proficiency or fluency cannot be transferred to students if the teacher is not equipped with 
adequate or sufficient pedagogical knowledge (Shulman, 1986; Vélez-Rendón, 2002, cited in Dincer A. et al., 2013). Shulman (1986, cited Park \& Lee, 2009) argued that pedagogical knowledge concerns ideas, concepts, analogies, explanations, and demonstrations that are used to make things discussed clearly and completely for students. Shulman's argument implies that the theories and methods of teaching foreign languages are crucial areas in foreign language education. These theories and methods must be studied in depth and become the core of foreign language education programs for prospective and in-service who are already on duty. Otherwise, the scholars who are related to science and/or observers and practitioners will ask for the "pie" of foreign language education.

The pedagogical knowledge of the relevant field in which the teacher must have something concerning their particular field. To make a general definition, Velez-Rendon (2002, cited in Dincer A. et al., 2013) concerns the knowledge of the fields concerned as what teachers know about what they teach. Buchman (1984, cited in Wilson, 2012) suggested the use of knowledge about the fields involved in different phases such as the use of target language effectiveness in the classroom, integrating lessons with students' backgrounds and preparing effective teaching plans. In addition to this item, different studies have contributed to the understanding of knowledge in the fields involved in different perspectives, for example from understanding the skills, accuracy, reading and pronunciation that need to be known for the targets to be achieved (Bautista, 2009; Park \& Lee, 2009; Fisher, 2012).

\subsection{Socio-Affective Skills}

Affective social skills as in all fields, are crucial where teachers must have some basic affective social skills to interact with their students and manage and maintain the learning process effectively. This capability includes broader things such as motivating students, providing time if students ask for help, being eager to teach, having a positive attitude towards students, being responsive to the needs of students and creating a stress-free atmosphere (Coleman, 2011; Shishavan \& Sadeghi, 2009). In addition to these aspects, Foote, Vermette, Wisniewski, Agnello, and Pegano (2000, cited in Wichadee, 2010) also state that teacher relations with students are a tense thing. In their study, Arikan, Taser and Sarac-Süzer (2009, cited in Vasuden, 2013) also highlighted the importance of creating and maintaining positive relationships with students. In addition, when trying to find similarities or differences in their studies and in the existing literature, Wilson (2012) raises and maintains the relation between the process of relations among members. According to his research, affective social skills enable teachers to create good results with their students as well as keep the learning process more effective and more successful.

\subsection{Teaching English as a Foreign Language in East Timor}

Following the 1999 elections that were independent from Indonesia, the East Timorese language policy became a topic of tough debate for various groups participating in the building of a new national identity. Since then, English has become the language used by the United Nations Transition Administration in East Timor (UNTAET), by a large number of international aid organizations and business companies, all of which can be compared to a new international 'invasion'. International English-language waves have an impact on language policy debates, and on the perceptions and expectations of language students and teachers (Barreto, 2007).

The gap caused by the withdrawal of teachers from Indonesia in 1999 resulted in foreign language teachers being filled by teachers from English-speaking countries, especially Australia. One special effect is the strong need for English, which is equally strong in the need for English teachers. In terms of international developers, these teachers become 'change agents', consultants and 'experts' in the process of teaching language (Savage, 1997, cited in Appleby, 2009), despite the lack of knowledge and experience about the social, cultural and political context of East Timor (Appleby, 2009).

While Portuguese is being promoted as the medium of instruction and considerable effort is being put into up-skilling the Portuguese language proficiency of teachers, English is already taught in secondary schools. The new pre-secondary (Years 7-9) curriculum introduced in 2011 retains English as a subject, and the planned senior secondary (Years 10-12) curriculum also included English. Teachers of English in secondary schools, however, typically lack high levels of English Language proficiency and have little or no training in language teaching methodology. Teachers of English have yet to receive any in-service training in their teaching area (Australian Government-DFAT, 2010).

\section{Theoretical Framework}

This study was guided by three theories namely (1) the Input Hypothesis theory (Krashen, 1999), (2) Dogme English Language Teaching (Medding \& Thornbury, 2009) and (3) Vygotsky's theory of value. The first two 
theories guide teachers how to motivate students. Motivation is one of the most important variables in teaching English. Krashen's theory emphasizes the importance of knowing the abilities and needs of students before teaching (Brown, 2003, cited in Rodrigo, 2004). Krashen's theory guides the teacher on motivating students to learn the target language. Students lose interest in learning the second language when the teacher uses a language which is too hard or too easy (Nikolov, 1997).

The Dogme English Language Teaching (DELT) is used to explain the teaching of English in the form of conversation, with little dependence on material that is usually used in urgent language teaching in the classroom (Meddings \& Thornbury, 2009). Wilson and Komba (2012) defines Dogme ELT as "both a way of teaching and an overt attitude to teaching". As the works cited imply, Dogme is clearly not a language teaching methodology per se. Rather, Dogme may be defined as a philosophy of teaching (Akca, 2012).

Vygotsky's value theory emphasizes the importance of looking at each child as an individual who learns differently. Consequently, there is a need for extensive knowledge and expertise about ways of learning that differ between individuals. The overall goal of education according to Vygotsky is to "generate and lead development which is the result of social learning through internalization of culture and social relationships." (Daydoy \& Keerr, 1995, cited in Makewa, 2013). He repeatedly emphasizing the importance of prior experience and initial knowledge in creating a sense of the new situation and current experiences. However, all new knowledge and newly introduced expertise is much influenced by the students' culture, especially the family environment (Fedom \& Vogel, 1993, cited in Sharaeai, 2012).

\section{Methodology}

This study used a descriptive correlational design to describe the relationship between English teachers' effectiveness and students' English proficiency at Canossa College, Dili - East Timor. In the study, the predictor variables are effectiveness of English teachers (in terms of English proficiency, pedagogical knowledge, and Socio-Affective skills); and the criterion variables are students' English proficiency (in terms of listening, speaking, reading, and writing).

The types of research data related to the selection of data sources and methods used. The methods of data collection were determined by the type and source of research data needed. The primary data were taken directly by researcher from the original source, not through intermediaries. The data primer specifically were collected by the researcher and related directly to the problems examined and to the secondary data. The primary data were obtained through the distribution of questionnaires directly to the respondents who are students of Canossa College, Dili - East Timor. For the interview, the researcher included five (5) English teachers. The qualitative data obtained through the interview supported the quantitative data gathered through the survey.

\section{Data Gathering Procedure and Data Analysis}

The study involved the students, teachers, dean and chairperson of Canossa College, Dili- East Timor. The researcher went to East Timor after getting the approval of the President of Canossa College. The researcher conducted interviews; distributed and retrieved the questionnaires personally from the respondents.

The Statistical Package for Social Sciences (SPSS) version 23 for Mac was to gather results from the collected data (Kulas, 2009). The qualitative data gathered from the interviews were analyzed. The analysis highlighted the transcribed data by summarizing, coding and categorizing to establish the main themes. The qualitative data supported the quantitative data.

\section{Result and Discussion}

Table 1. Level of English teachers' effectiveness as assessed by the student respondents in terms of English proficiency

\begin{tabular}{|c|c|c|c|}
\hline English Proficiency & Mean & $\begin{array}{l}\text { Qualitative } \\
\text { Description }\end{array}$ & Interpretation \\
\hline 1. Understand spoken English well. & 3.79 & Agree & Effective \\
\hline 2. Know English culture well. & 3.64 & Agree & Effective \\
\hline 3. Read English well. & 3.75 & Agree & Effective \\
\hline 4. Have a high level proficiency with English vocabulary. & 3.67 & Agree & Effective \\
\hline 5. Write English well. & 3.68 & Agree & Effective \\
\hline
\end{tabular}


6. Pronounce English well.

7. Speak English well.

8. Be fully conversant with English grammar.

9. Speak English with native speaker control of accent, intonation, and fluency.

10. Use easy language to aid student understanding.

Composite Mean

$\begin{array}{lll}3.19 & \text { Neutral } & \text { Average } \\ 3.64 & \text { Agree } & \text { Effective } \\ 3.68 & \text { Agree } & \text { Effective } \\ 3.68 & \text { Agree } & \text { Effective } \\ 3.65 & \text { Agree } & \text { Effective } \\ \mathbf{3 . 6 3} & \text { Agree } & \text { Effective }\end{array}$

Legend: 4.51-5.00 Strongly Agree/Highly Effective; 3.51-4.50 Agree/Effective; 2.51-3.50 Neutral/Average; 1.51-2.50 Disagree/Not Effective; 1.00-1.50 Strongly Disagree/Highly Ineffective.

Among the ten (10) sub-variables, "Understand spoken English well" got the highest mean score of 3.79, interpreted as effective. "Pronounce English well" obtained the lowest mean score of 3.19, interpreted as average. The composite mean for the "English Proficiency" variables is 3.63, interpreted as effective.

The English Proficiency of the English teachers is effective. However, it is necessary to pay attention to the "Pronounce English well" which obtained average level. Widoyoko (2013) interpreted neutral as average which is often associated with "slightly below average".

Rahul (2015) pointed out that certain English Foreign Language learners often make pronunciation errors that are usually thought to be due to the influence of their native language, particularly, consonant phonemes exist in English, but not in other languages.

Table 2. Level of English teachers' effectiveness as assessed by the student respondents in terms of pedagogical knowledge

\begin{tabular}{|c|c|c|c|}
\hline Pedagogical Knowledge & Mean & $\begin{array}{l}\text { Qualitative } \\
\text { Description }\end{array}$ & Interpretation \\
\hline 1. $\quad$ Prepare the lesson well. & 3.73 & Agree & Effective \\
\hline 2. Teach how to learn English outside the classroom. & 3.61 & Agree & Effective \\
\hline $\begin{array}{l}\text { 3. Use various material including video, audio, and } \\
\text { multimedia. }\end{array}$ & 3.36 & Neutral & Average \\
\hline $\begin{array}{l}\text { 4. Teach English tailored to students' English proficiency } \\
\text { level. }\end{array}$ & 3.72 & Agree & Effective \\
\hline $\begin{array}{l}\text { 5. Maintain good classroom atmosphere using authority, if } \\
\text { necessary. }\end{array}$ & 3.79 & Agree & Effective \\
\hline 6. Teach English in English. & 3.69 & Agree & Effective \\
\hline 7. Assess what students have learned rationally. & 3.69 & Agree & Effective \\
\hline $\begin{array}{l}\text { 8. Teach English incorporating student's various learning } \\
\text { styles. }\end{array}$ & 3.62 & Agree & Effective \\
\hline $\begin{array}{l}\text { 9. Provide opportunities to use English through meaningful } \\
\text { activities. }\end{array}$ & 3.67 & Agree & Effective \\
\hline $\begin{array}{l}\text { 10. Use predominantly real-life materials (e.g., music, pictures, } \\
\text { food, and clothing) in teaching both language and the culture. }\end{array}$ & 3.40 & Neutral & Average \\
\hline Composite Mean & 3.63 & Agree & Effective \\
\hline
\end{tabular}

Legend: 4.51-5.00 Strongly Agree/Highly Effective; 3.51-4.50 Agree/Effective; 2.51-3.50 Neutral/Average; 1.51-2.50 Disagree/Not Effective; 1.00-1.50 Strongly Disagree/Highly Ineffective.

From ten (10) different sub-variables under Pedagogical Knowledge of English teachers "Maintain good classroom atmosphere using authority, if necessary" got the highest mean score of 3.79, interpreted as effective. "Use various material including video, audio, and multimedia" obtained the lowest mean score of 3.36, 
interpreted as average. The second lowest mean score of 3.40, interpreted as average refers to "Use predominantly real-life materials (e.g., music, pictures, food, and clothing) in teaching both language and the culture". The composite mean for Pedagogical Knowledge is 3.63, interpreted as effective.

The two sub-variables categorized as average relate to the skills to utilize technology, media, and materials in teaching English. This is about how to plan and deliver lessons that effectively integrate technology into their classroom teaching. The low score indicates the influence of a book-centered teaching methods where teachers and students are more focused on following the steps specified in the lesson plan and completing the materials and exercises described in the manual-book.

The use of teaching materials has a large impact on activities in language teaching. Abedi (2009) pointed out that students will be eager to learn vocabulary with the help of visual material; and the use of visual material will enrich the ability of students and the opportunity to use language to express their thoughts and feelings (Nadia, 2015).

Table 3. Level of English teachers' effectiveness as assessed by the student respondents in terms of socio-affective skills

\begin{tabular}{|c|c|c|c|}
\hline Socio-Affective Skills & Mean & $\begin{array}{l}\text { Qualitative } \\
\text { Description }\end{array}$ & Interpretation \\
\hline $\begin{array}{l}\text { 1. Help students in and outside of the classroom with their } \\
\text { difficulties in learning English. }\end{array}$ & 3.68 & Agree & Average \\
\hline 2. Alleviate students' anxiety in English class. & 3.73 & Agree & Effective \\
\hline 3. Entertain students' questions on English learning. & 3.73 & Agree & Effective \\
\hline 4. Help students' self-confidence in learning English well. & 3.74 & Agree & Effective \\
\hline 5. Are concerned and supportive of students' learning. & 3.79 & Agree & Effective \\
\hline 6. Have clear goals and understand learners' needs. & 3.78 & Agree & Effective \\
\hline $\begin{array}{l}\text { 7. Treat students who differ in terms of English abilities and } \\
\text { skills fairly. }\end{array}$ & 3.70 & Agree & Effective \\
\hline 8. Arouse students' motivation for learning English. & 3.69 & Agree & Effective \\
\hline $\begin{array}{l}\text { 9. Have interest in students (e.g. remembering students' } \\
\text { name) and students' English learning. }\end{array}$ & 3.68 & Agree & Effective \\
\hline 10. Make sure students feel at home in the classroom. & 3.36 & Neutral & Average \\
\hline Composite Mean & 3.66 & Agree & Effective \\
\hline
\end{tabular}

Legend: 4.51-5.00 Strongly Agree/Highly Effective; 3.51-4.50 Agree/Effective; 2.51-3.50 Neutral/Average; 1.51-2.50 Disagree/Not Effective; 1.00-1.50 Strongly Disagree/Highly Ineffective.

From the ten (10) different sub-variables under Socio-Affective Skills, "Are concerned and supportive of students' learning" got the highest mean score of 3.79, interpreted as effective. "Make sure students feel at home in the classroom" obtained the lowest mean score of 3.36, interpreted as average. The composite mean for Socio-Affective Skills is 3.66, interpreted as effective.

Socio-affective skills refers to a set of competencies to interact with their students and maintain the teaching process effectively. This expertise concerns broader broader skills such as motivating students, providing time if students ask for help, being eager to teach, having a positive attitude towards students, being responsive to the needs of students and creating a stress-free atmosphere (Sishavan \& Sadeghi, 2009) . In addition to these aspects, Foote, Vermette, Wisniewski, Agnello, and Pegano (2000, cited in Wichadee, 2010) also state that teacher relations with students are a tense thing.

In their study, Bautista (2009) also highlighted the importance of establishing and maintaining positive relationships with students. Besides, when trying to find similarities and differences between his study and the existing literature, Innotech (2010) maintains the significance of the relationship between the members of the process. The socio-affective skills enable teachers to establish good rapport with their students as well as maintaining the process of education more effectively and successfully. 
Table 4. The level of the English proficiency of the student respondents in terms of listening, writing, reading, and speaking

\begin{tabular}{|c|c|c|c|}
\hline Components & Mean & Qualitative Description & Interpretation \\
\hline 1. Listening & 3.62 & $\begin{array}{l}37-42 \text { scores } \\
\text { out of total of } 50\end{array}$ & Good \\
\hline 2. Writing & 4.11 & $\begin{array}{l}37-42 \text { scores } \\
\text { out of total of } 50\end{array}$ & Good \\
\hline 3. Reading & 4.17 & $\begin{array}{l}37-42 \text { scores } \\
\text { out of total of } 50\end{array}$ & Good \\
\hline 4. Speaking & 3.51 & $\begin{array}{l}\text { Mostly appropriate in Grammatical, Pronunciation, } \\
\text { and Language of Interaction }\end{array}$ & Good \\
\hline Over-all Mean & 3.85 & $\begin{array}{l}\text { 37-42 scores } \\
\text { Mostly appropriate }\end{array}$ & Good \\
\hline
\end{tabular}

Legend: 4.51-5.00 Very Good; 3.51-4.50 Good; 2.51-3.50 Average; 1.51-2.50 Limited; 1.00-1.50 Very Limited.

Reading obtained the highest mean score of 4.17, interpreted as good. Speaking got the lowest mean of 3.51, interpreted as good. The over-all mean for Student-Respondents' Level of English Proficiency is 3.85, interpreted as good. Observing closely, the mean score of Speaking is close to "Average" (down) because in the Range of Mean Values, the range of $2.51-3.50$ is Average.

The speaking skill and the communicative fluency of the students are also linked to the method and teaching technique used by the teachers in the classroom. Poornima (2014) found out that the Grammar-Translation Method has been used by the language teachers for several years. It is also known as the Classical method as it was used to teach the classical Latin and Greek literature (Chastain, 1988, cited in Zamani \& Ahangari, 2016). It was believed that this method would help students to read and appreciate foreign literature. It was also thought that by studying the grammar of the target language, students will be able to understand the grammar of their native language, and learn to speak and write the native language in a much better way.

Based on the observations of the researcher in the English classes in some schools in Dili, and through the interviews with a number of English teachers; he saw that in reality, still a lot of teachers still use the Grammar-Translation Method' which of course does not develop much the speaking ability of the Timorese students.

Furthermore, studying English as foreign language takes place only in the classroom where the amount of time devoted to learn English is not sufficient at all to the extent of not allowing the students to practice the language amply (Horta, 2012). The prevalent use of Tetun (or Tetum) Portuguese is another factor that makes English not to be considered significant as means of international linguistic communication fully (Appleby, 2009; Da Silva, 2013).

Table 5. Significant relationship between the level of English teachers' effectiveness and level of students' English proficiency

\begin{tabular}{|c|c|c|c|c|c|}
\hline $\begin{array}{l}\text { English } \\
\text { Effectiveness }\end{array}$ & $\begin{array}{l}\text { Students' } \\
\text { Proficiency }\end{array}$ & Computed $\mathrm{r}$ & Sig & $\begin{array}{l}\text { Decision } \\
\text { Ho }\end{array}$ & Interpretation \\
\hline \multirow{4}{*}{ 1. English Proficiency } & Listening & 0.70 & 0.00 & Rejected & Significant \\
\hline & Writing & 0.62 & 0.00 & Rejected & Significant \\
\hline & Reading & 0.73 & 0.00 & Rejected & Significant \\
\hline & Speaking & 0.71 & 0.00 & Rejected & Significant \\
\hline \multirow{3}{*}{ Pedagogical Knowledge } & Listening & 0.65 & 0.00 & Rejected & Significant \\
\hline & Writing & 0.57 & 0.00 & Rejected & Significant \\
\hline & Reading & 0.63 & 0.00 & Rejected & Significant \\
\hline
\end{tabular}




\begin{tabular}{llllll}
\hline & Speaking & 0.62 & 0.00 & Rejected & Significant \\
& Listening & 0.62 & 0.00 & Rejected & Significant \\
3. Socio-Affective Skills & Writing & 0.54 & 0.00 & Rejected & Significant \\
& Reading & 0.62 & 0.00 & Rejected & Significant \\
& Speaking & 0.56 & 0.00 & Rejected & Significant \\
& Listening & 0.70 & 0.00 & Rejected & Significant \\
& Writing & 0.61 & 0.00 & Rejected & Significant \\
& Reading & 0.70 & 0.00 & Rejected & Significant \\
& Speaking & 0.68 & 0.00 & Rejected & Significant \\
\hline
\end{tabular}

Correlation measures the linear association between two variables. Correlation (computed r) can take values between negative 1 to positive 1 . It can be interpreted as follows: 0 means "No Relationship", \pm 0.01 to \pm 0.24 means "Very Low or Weak Relationship", \pm 0.25 to \pm 0.49 means "Moderate Relationship", \pm 0.50 to \pm 0.74 means "High or Strong Relationship", \pm 0.75 to \pm 0.99 means "Very High or Very Strong Relationship" and \pm 1 means "Perfect Relationship".

The Pearson Correlation shows that students' proficiency in English language is correlated with English Proficiency, Pedagogical Knowledge, and Socio-Affective Skills of the teachers. In other words, the results show that the higher students' proficiency of the English language in terms of Listening, Writing, Reading and Speaking is related with higher English teachers' English Proficiency, Pedagogical Knowledge, and Socio-Affective Skills.

Nel and Müller (2010) found out the impact of teachers' limited English proficiency on English second language learners in South African schools. The lack of competence of English teacher will also have negative effect on students' English proficiency. Riasati and Bagheri (2014) saw the "paradox of the primary school professional" referring to teachers of literacy who are themselves unskilled and do not read due to a strong oral culture and lack of reading materials affecting their learners' acquisition of English. The results indicated that various forms of English language errors were transferred to learners.

Albakrawi (2014) concluded that the ability and competencies of the English teachers affect the student's English proficiency. The native English teachers have their own advantages and strong points compared with the non-native English instructors. Being a native speaker of the language also means being a representative of the community speaking that language with all its values, habits, cultures traditions and norms as mentioned by Kariminia and Salehizadeh (2009). They may have more influence in the fluency and accent of the students than the non-native teachers; and the outputs is positive in foreign language learning. These result correlate strongly with the result of another study conducted in the state of Kuwait.

\subsection{Opportunities and the Challenges That the Teachers Encountered in Teaching}

The English teachers encountered 10 aspects of the opportunities and challenges in teaching English namely: (1) Motivation to study English, (2) Unfamiliarity with technical English, (3) Vocabulary deficiency, (4) Dictionary dependency, (5) English textbook deficiency, (6) Language policy, (7) Use English outside classroom, (8) English is treated as a subject to study, not a skill to acquire, (9) Students are passive participants, and (10) Homophones.

From the ten (10) topics, there are two most prominent topics in which all teachers assessed as opportunities and challenges they encountered in teaching English. The two themes are (1) Motivation to study English, and (2) Use English outside of classroom.

\section{Conclusion}

All the aspects of the independent variables (English teachers' effectiveness) are correlated with the aspect of dependent variable (students' English proficiency). The correlation coefficient values are between of \pm 0.50 to \pm 0.74. It means "High or Strong Relationship". There are two (2) from ten (10) most prominent topics in which all teachers assessed as opportunities and challenges they encountered in teaching English. The two themes are (1) Motivation to study English, and (2) Use English outside of classroom.

Effective teaching leads to effective learning in learners, and the most important aim of English classes in a country like East Timor is effective learning. English proficiency, pedagogical knowledge, and socio-affective 
skills and strategies also pave the way for effective teaching of teachers. Teachers who do not have enough of English proficiency, pedagogical knowledge, and socio-affective skills often have problems in their teaching and passing the knowledge to the learners and find it impossible to build English proficiency in them. The findings of this study and future studies will contribute to more complete knowledge-based teacher education for English teachers in East Timor.

\section{Recommendations}

The management and the English teachers of Selected Colleges in Dili, East Timor may consider reviewing the curriculum on the aspect of speaking skills and promoting the use of English outside of classroom. As this study noted, the level of Speaking is "Good", but it seem close to the level of Average.

Future researchers may want to replicate the study using larger sample of students in a larger geographical area (for example schools in a diocese, municipality or districts).

Other researchers may opt to investigate other variables that might relate to the students' English proficiency such as motivation, metacognitive skills, school culture and organizational climate of the schools.

Longitudinal studies with the same variable may be conducted to determine whether changes occur within the individual or group over the course of time. Lastly is the training programs for the English teachers and students may be proposed to enhance their English proficiency growth.

\section{References}

Akça, C. (2012). Dogme unplugged. Paper presented at the International Symposium on Language and Communication: Research Trends and Challenges in Erzurum, Turkey.

Albakrawi, H. T. M. (2014). Is there a difference between native and non-native English teacher in teaching English? Journal of Scientific Research and Studies, 1(6).

Almeide, P., \& Martinho, M. (2014). The empowerment of education in East Timor through in-service teacher training. Procedia - Social and Behavioral Sciences, 191, 2364-2368. https://doi.org/10.1016/j.sbspro. 2015.04.420

Appleby, R. (2009). English language and East Timor: Globalization and local identity. University of Technology, Sydney.

Barreto, A. S. (2009). Multi-language policy in East Timor public sector. Implication on capacity building and a proposed strategy to address it. The University of Waikato, New Zealand.

Bautista, M. L. S., \& Gonzales, A. B. (2009). Southeast Asian Englishes. In B. Kacharu, Y. Kacharu, \& C. L. Nelson (Eds.), The Handbook of World Englishes (pp. 130-144). Oxford: Blackwell Publishing Ltd.

Coleman, H. (2011). Dreams and realities: Developing countries and the English language. London: British Council.

Chuah, S. (2009). Teaching East-Asian Students: Some Observations. Economicsnetwork.ac.uk/Showcase.

Da Silva, S. J. (2013). Lusophonization returns? The condition of language policy and planning in a post-colonial plurilingual Timor Leste. The University of Waikato, New Zealand.

Dincer, A. (2013). Common characteristics of an effective English language teacher. Educational Research Association the International Journal of Education Researchers, 4(2), 388-45.

Dos Santos, M., \& Belo, D. X. (2009). Quality teacher education in Timor Leste: A growing reality. Instituto Cathólico para a Formação de Professores. Catholic Teachers College, Baucau.

Fakeye, D. D., \& Yemi, O. (2009). English language proficiency as a prediction of academic achievement among EFL students in Nigeria. European Journal of Scientific Research, 37(3), 490-495.

Fisher, D. (2012). School culture: Creating a unified culture of learning in a multi-cultural setting. Presented on Regional Conference, Madrid 2012.

Frankel, J. R., \& Wallen, N. E. (2009). How to design and evaluate research in education. New York: McGraw-Hill.

Government of Timor-Leste. (2010). Australia-East Timor English Language Program: Project Design Document. Retrieved from https://dfat.gov.au/aboutus/publications/Documents/australia-timor-lestelanguage-program-design.pdf

Horta, R. J. (2012). Timor Leste language policy: Tetum, Portuguese, Bahasa Indonesia or English? Retrieved 
from http://www.eurasiareview.com/2012

Innotech, S. (2010). Teaching competency standards in Southeast Asian countries: Eleven country audit. Philippine Copyright 2010. SEAMEO INNOTECH - ISBN 978-971.

Kariminia, A., \& Salehizadeh, S. (2009). Communication Strategies: English language departments in Iran. Iranian Journal of Language Studies, 1(4), 287-300.

Krashen, S. (1999). Seeking a Role for Grammar: A Review of Some Recent Studies. Foreign Language Annals, 32(2), 245-57. https://doi.org/10.1111/j.1944-9720.1999.tb02395.x

Kulas, J. T. (2009). SPSS Essentials: Managing and analyzing social sciences data. San Francisco: Jossey-Bass.

Makewa, L. N., \& Role, E. (2013). Students' perceived level of English proficiency in secondary school in Dodoma, Tanzania. International Journal of Instruction.

Meddings, L., \& Thornbury, S. (2009). Teaching unplugged. Survey: Delta Publishing.

Mutlu, A. K., \& Ozkan, Y. (2017). Pre-service English language teachers' views of the effective teacher and teaching. Mediterranean Journal of Humanities, VII(1), 213-231. https://doi.org/10.13114/MJH.2017.332

Nara, M. M. (2015). Impact of English proficiency on academic performance of international students. Journal of International Students, 5(1), 60-71.

Negari, M. N., \& Heydari, J. (2014). An investigation into the relationship between Iranian English foreign language teachers' self-regulation and effective teaching. International Journal of Language Learning and Applied Linguistics Word (IJLLALW), 7(2), 288-299.

Nel, N., \& Müller, H. (2010). The impact of teachers' limited English proficiency on English second language learners in South African schools. South African Journal of Education, 30, 635-650. https://doi.org/ 10.15700/saje.v30n4a393

Nikolov, M., \& Krashen, S. (1997). Need We Sacrifice Accuracy for Fluency? System, 25(2), 197-201. https://doi.org/10.1016/S0346-251X(97)00008-0

Noora, A. (2009). Iranian undergraduate non-English majors' language preferences. GEMA Online Journal of Language Studies, 8(2), 33-34.

Park G., \& Lee, H. (2009). The characteristics of effective English teachers as perceived by high school teachers and students in Korea. Asia Pacific Education Review, 7(2), 236-248. https://doi.org/10.1007/BF03031547

Phlong, P. (2012). About East Timor. In Southeast Asia Digital Library. Retrieved from http://sea.lib.niu.edu/country/about_easttimor

Poornima, R. S. (2014). Dogme ELT: A method for enhancing conversational communication among engineering students. Department of English, Jerusalem College of Engineering, Chennai, India. IOSR Journal of Humanities and Social Science (IOSR-JHSS), 19(7), 33-35. https://doi.org/10.9790/0837-19753335

Quinto, E. J. M. (2015). English in East Timor: Functions, Policy and Future Directions. SLHS-Department of Communication, Mapua Institute Technolog, Manila, Philippines.

Rahul, R. (2015). A study on dogme English teaching theory. International Journal of English Language, Literature and Translation (IJELR), 2(4).

Ravasi, D., \& Schultz, M. (2009). Responding to organizational identity threats: Exploring the role of organizational culture. Academy of Management Journal, 49(3), 433-458. https://doi.org/10.5465/ amj.2006.21794663

Riasati, M. J., \& Bagheri, M. S. (2014). Students' perception of effective teaching: A review of literature. International Journal of Language Learning and Applied Linguistics World (IJLLALW), 6(3), 420-428.

Rodrigo, V., Krashen, S., \& Gribbons, B. (2004). The Effectiveness of Two Comprehensible-Input Approaches to Foreign Language Instruction at the Intermediate Level. System, 32(1), 53-60. https://doi.org/10.1016/ j.system.2003.08.003

Sary, F. P. (2015). Students' perception of English learning difficulties and strategies. Indonesian EFL Journal, $1(1)$.

Shaik, F. S. (2015). Effective methods of teaching English as a second language in the classroom. International Journal of Science and Research (IJSR), 4(2).

Sharaeai, W. A. (2012). Students' perspectives on the use of L1 in English classrooms. Digital Repository @ 
Iowa State University.

Silalahi, R. M. (2016). English teachers' perspectives on the impact of English as a global language influencing the Indonesian educational system. Prosiding ICTTE FKIP UNS 2015, 1(1).

Silva, S. J. D. (2013). Lusophonization returns? The condition of language policy and planning in a post-colonial plurilingual Timor Leste. The University of Waikato, New Zealand.

Siregar, F. L. (2010). The language attitudes of students of English literature and D3 English at Maranatha Christian University towards American English, British English and Englishes in Southeast Asia. Philippine ESL Journal, 4, 66-92.

Sishavan, H. B., \& Sadeghi, K. (2009). Characteristics of an effective English Language Teacher as Perceived by Iranian Teachers and Learners of English. English Language Teaching, 2(4). https://doi.org/10.5539/ elt.v2n4p130

Taylor-Leech, K. J. (2009). The ecology of language planning in Timor Leste. A study of language policy, planning and practices in identity construction. Griffith University, Brisbane, Australia. https://doi.org/10.1080/14664200802339840

Vasudevan, H. (2013). The influence of teachers' creativity, attitude and commitment on students' proficiency of the English language. ISOSR Journal of Research \& Method in Education, 1(2), 12-19. https://doi.org/ $10.9790 / 7388-0121219$

Vizcarra Florante, O., \& Lubina Eduardo, G. (2012). Work-text in statistics. Quezon City: Great Books Publishing.

Vu, P. T. (2014). English in Southeast Asian countries. HAL Id: dumas-00931949.

Wakita, H. (2013). Quality assurance of English language teachers: A missing paradigm in teacher education. Working Paper Series Studies on Multicultural Societies, 13.

Wichadee, S. (2010). Defining the effective English language teacher: Students' and teachers' perspective. In A. M. Stoke (Ed.), JALT 2009 Conference Proceedings. Tokyo: JALT.

Widoyoko, R. (2013). Tekhnik penyusunan instrument penelitian. Yogyakarta: P.T. Pustaka Belajar.

Wilson, J., \& Komba, S. C. (2012). The link between English language proficiency and academic performance: A pedagogical perspective in Tanzanian secondary schools. World Journal of English Language, 2(4). https://doi.org/10.5430/wjel.v2n4p1

Xerri, D. (2012). Experimenting with dogme in mainstream of English as second language (ESL) context. English Language Teaching, 5(9). https://doi.org/10.5539/elt.v5n9p59

Young, R. F. (2009). English and Identity in Asia. Asiatic, 2(2), 1-13.

Zamani, R., \& Ahangari, S. (2016). Characteristics of an effective English language teacher (EELT) as perceived by learners of English. International Journal of Foreign Language Teaching \& Research, 14(4).

\section{Copyrights}

Copyright for this article is retained by the author(s), with first publication rights granted to the journal.

This is an open-access article distributed under the terms and conditions of the Creative Commons Attribution license (http://creativecommons.org/licenses/by/4.0/). 